\title{
A South African perspective on livestock production in relation to greenhouse gases and water usage
}

\author{
M.M. Scholtz ${ }^{1,2 \#}$, J.B.J. van Ryssen ${ }^{3}$, H.H. Meissner ${ }^{4}$ \& M.C. Laker ${ }^{5}$ \\ ${ }^{1}$ ARC-Animal Production Institute, Private Bag X2, Irene, 0062, South Africa; ${ }^{2}$ University of the Free State, PO Box \\ 339, Bloemfontein, 9300, South Africa; ${ }^{3}$ Department of Animal \& Wildlife Sciences, University of Pretoria, Pretoria, \\ 0002, South Africa; 189 van Riebeeck Avenue, Lyttelton Manor, Centurion 0157, South Africa; ${ }^{5} 477$ Rodericks Road, \\ Lynnwood 0081, South Africa
}

Copyright resides with the authors in terms of the Creative Commons Attribution 2.5 South African Licence.

See: http://creativecommons.org/licenses/by/2.5/za

Condition of use: The user may copy, distribute, transmit and adapt the work, but must recognise the authors and the South African Journal of Animal Science

\begin{abstract}
The general perception that livestock is a major contributor to global warming resulted mainly from the FAO publication, Livestock's Long Shadow, in 2006, which indicated that livestock is responsible for $18 \%$ of the world's greenhouse gas (GHG) emissions. This figure has since been proved to be an overestimation, since it includes deforestation and other indirect contributions. The most recent figure is in the order of $5 \%-10 \%$. Although only ruminants can convert the world's high-fibre vegetation into highquality protein sources for human consumption, ruminant production systems are targeted as they are perceived to produce large quantities of GHG. Livestock is also accused of using large quantities of water, an allegation that is based on questionable assumptions and the perception that all sources of food production require a similar and equal quantity and quality of water. In the case of ruminants, extensive systems are usually found to have a lower per-area carbon footprint than grain-fed systems, but a higher footprint if expressed in terms of kg product. Feedlots maximize efficiency of meat production, resulting in a lower carbon footprint, whereas organic production systems consume more energy and have a bigger carbon footprint than conventional production systems. Cows on pastures produce more methane than cows on high concentrate diets. In South Africa, as in most of the countries in the sub-tropics, livestock production is the only option on about $70 \%$ of the agricultural land, since the marginal soils and rainfall do not allow for crop production and the utilization of green water. An effective way to reduce the carbon and water footprint of livestock is to decrease livestock numbers and increase production per animal, thereby improving their efficiency.
\end{abstract}

Keywords: Animal products, carbon footprint, green and blue water, human nutrition, production systems, methane, water usage

"Corresponding author: GScholtz@arc.agric.za

\section{Introduction}

There is a general perception that livestock is a major contributor to global warming. This is based on an FAO publication, Livestock's Long Shadow, (Steinfeld et al., 2006), which indicated that livestock is responsible for $18 \%$ of the world's greenhouse gas (GHG) emissions. This figure has since been proven to be an overestimation of the contribution of agriculture since it includes deforestation and other indirect contributions (Pitesky et al., 2009). The most recent global figure is of the order of $5 \%-10 \%$, with the figure for South Africa being similar (Meissner et al., 2012). Livestock contributes about 65\% of agricultural GHG ( $\mathrm{CO}_{2}$ equivalent) of which enteric fermentation accounts for $90 \%$ (Meissner et al., 2012). In general, 
estimates of emissions from livestock are subject to uncertainty because generic coefficients applicable to all animals are commonly used which take no account of differences in production efficiency and production systems (Scollan et al., 2010).

Quoting percentages does not always make sense. In industrialized countries the GHG emissions for agriculture are less than $6 \%$, simply because the contribution of their energy sectors, mines, etc., to GHG emissions is large. In non-industrialized countries the relative contribution by agriculture can be $40 \%-50 \%$, but the actual contribution can be considerably less than the $6 \%$ by the industrialized countries. When considering mitigation options, it is obvious that a $10 \%$ reduction in GHG emissions by the energy and mining sectors would be far more effective than a $10 \%$ reduction in the $5 \%-10 \%$ contribution of agriculture. So, the proposed "meat-free once a week" argument will not do much to rectify the problem (Meissner et al., 2012) as other sources of protein for human consumption are required, which may even have a higher carbon footprint.

Greenhouse gas emission from livestock is usually calculated in terms of $\mathrm{kg} \mathrm{CO}_{2}$ equivalent per $\mathrm{kg}$ of meat or milk available for consumption or per area of land used. In the case of ruminants, extensive systems are usually found to have a lower per-area footprint than intensive grain-fed systems, but a higher footprint if expressed in terms of kg product (Garnett, 2010; Capper, 2011).

Livestock is also accused of using large quantities of water in the production of beef or milk. Some of the assumptions used to calculate the water footprint or the amount of water required to produce livestock products are questionable (Meissner et al., 2012). In studies with more realistic and justifiable assumptions, the water requirement for red meat production (Peters et al., 2010) and for the production of total milk solids in whole milk and in skim milk powder is much lower (Ridoutti et al., 2010).

Herbivores are important to humankind since most of the world's vegetation biomass is rich in fibre. Only herbivores can convert this high fibre vegetation into high-quality protein sources (i.e. meat and milk) for human consumption and this will need to be balanced against the concomitant production of methane. Despite this important role of herbivores, they are being targeted and singled out as producing large quantities of GHG, which contribute to climate change, as enteric fermentation is responsible for $28 \%$ of global methane emissions (IPCC, 2007), and as using large quantities of water.

Many consumers may decide to reduce their red meat consumption because of the perception of the contribution to methane production by livestock and the low water productivity of animal products per unit of water used (Renault \& Wallender, 2000; Wenhold et al., 2007). The popular press is fuelling these sentiments, encouraging consumers to eat less meat.

But in terms of protein produced per unit of water, animal products are far more efficient than fruit crops and several other food crops, such as grains and vegetables (Renault \& Wallender, 2000; Wenhold et al., 2007). Furthermore, the importance of animal products in providing bio-available mineral nutrients (Laker, 2005) is overlooked. If the predictions are correct the demand for livestock products will continue to increase in future, but will progressively be affected by competition for natural resources, contention over feed and human food and the need to operate in a carbon constrained (Thornton, 2010) and water shortage economy.

\section{Focus on methane}

If enteric fermentation is responsible for $28 \%$ of global methane emissions (US-EPA, 2006) and methane makes up $18 \%$ of total world GHG emissions (Table 1), the net contribution of enteric fermentation to GHGs is only $5 \%(28 \%$ of $18 \%=5 \%)$. The major GHGs related to livestock production, converted to carbon dioxide $\left(\mathrm{CO}_{2}\right)$ equivalent and their characteristics (heating potential, atmospheric lifetime) are summarized in Table 1.

South Africa is part of the Kyoto Protocol and the government has set a reduction target of $30 \%-40 \%$ in $\mathrm{CO}_{2}$-equivalent emissions from the 2003 levels by 2050 in line with the Kyoto Protocol (UNFCCC, 2007). Reduction in $\mathrm{CH}_{4}$ levels will thus have a significant effect on the targets set by government since its impact will be faster owing to the shorter lifetime and greater owing to the higher heating potential, compared with $\mathrm{CO}_{2}$. More emphasis on the reduction of $\mathrm{CH}_{4}$ emissions can thus be expected in the immediate future if reduction targets are to be met. 
Table 1 Major greenhouse gases (GHG) related to livestock production converted to $\mathrm{CO}_{2}$ equivalent and their characteristics (Adapted from Clark et al., 2001, IPCC, 2007 and Biotech Ltd, 2009)

\begin{tabular}{lccc}
\hline GHG & $\mathrm{CO}_{2}$ & $\mathrm{CH}_{4}$ & $\mathrm{~N}_{2} \mathrm{O}$ \\
\hline Atmospheric concentration & 49 & 18 & 6 \\
Atmospheric lifetime (years) & $100-200$ & 12 & 114 \\
Heating potential & 1 & 23 & 296 \\
\hline
\end{tabular}

\section{Livestock production systems and production of greenhouse gasses}

Livestock agriculture is the world's largest user of land resources and South Africa is no different. In South Africa approximately $84 \%$ of the surface area is available for farming. However, a large part of this is not suitable for crop production, with approximately 13\% that is arable. The greater part of South Africa (approximately 70\%) is suitable only for extensive livestock farming (RMRD SA, 2012). In Africa, subsistence farmers keep livestock for multiple purposes. Rural households depend on livestock for milk, meat, hides, horns, fertilizer and income (Chimonyo et al., 1999; Dovie et al., 2006) making it central to the livelihoods and wellbeing of rural communities.

In spite of primary beef cattle farming (cow-calf production cycle) being largely extensive in South Africa, more than $75 \%$ of cattle slaughtered in the formal sector is finished in feedlots on maize and its byproducts (RMRD SA, 2012).

The cow-calf portion of the production cycle (the extensive part in South Africa) accounts for $72 \%$ of the nutrient requirements from conception to harvest (Ferrell \& Jenkins, 1982). Under natural rangeland conditions, decomposition of manure is aerobic, leading to production of $\mathrm{CO}_{2}$ and $\mathrm{H}_{2} \mathrm{O}$ as end products. Part of the $\mathrm{CO}_{2}$ released from the aerobic digestion of manure is absorbed during the regrowth of the surrounding vegetation rather than released into the atmosphere. The carbon sequestration measurement of this has been neglected and therefore the quantitative effect is not known. This is in sharp contrast to intensive systems in large parts of Europe and North America, where large quantities of manure are stockpiled, often for long periods, and undergo anaerobic decomposition. Anaerobic decomposition of manure, as found in intensive cow-calf systems, feedlots and intensive dairy systems, produces $\mathrm{CH}_{4}$ as one of the major end products (AAFRD, 2004; Wilkie, 2005).

It is also relevant to consider calf finishing systems or the post weaning phase. Cattle in South Africa are fattened in feedlots for approximately 110 days, which means that they produce GHG for only 110 days before being slaughtered. For cattle on rangeland/pasture it requires more than 200 days to finish to the same carcass classification because of the lower-quality feed compared with a feedlot diet (Meissner et al., 2012). Furthermore, the lower-quality feed (mainly natural pastures) results in cattle producing more GHG per kilogram feed intake than the concentrated diets being fed in feedlots (Capper, 2011; Meissner et al., 2012). This results in feedlots maximizing efficiency of meat production resulting in a lower carbon footprint per kilogramme of beef.

Furthermore, substantial evidence indicates that organic production systems consume more energy and have a bigger carbon footprint than conventional production systems. For example, organic grass-fed cattle require approximately three times more energy per kilogramme of weight gain, and release more than double the quantity of GHGs per kilogramme of weight gain of conventional feedlot cattle (Capper, 2010). Most consumers purchasing organic products do not know that such systems have a higher carbon footprint.

Dairy cows on pastures produce more methane than cows on high concentrate diets. At a recent World Congress, it was concluded that increasing cow efficiency, which is maintaining milk output from fewer animals, reduced farm methane production by 15\% (Gibson, 2010). A study in the USA indicated that the carbon footprint per kilogramme milk produced in 2007 was only $37 \%$ of that produced in 1944 . Thus the carbon footprint of milk currently produced is $63 \%$ smaller than the mostly natural production systems of 1944 (Capper et al., 2009). At least four studies in the USA on milk production confirmed that production is $15 \%$ - 27\% lower in organic than in conventional systems (Meissner et al., 2012). In addition, when 
differences in productivity were accounted for, the organic systems required more resources (land, feed, water, etc.) per unit of milk produced and the environmental impact was greater.

\section{Livestock production systems and water usage}

The likelihood of extreme events such as more frequent droughts and floods, coupled with a general scarcity of and poor water quality in South Africa, is a signal that global warming could have a major impact on water resources. The water footprint or the amount of water required to produce $1 \mathrm{~kg}$ product is therefore of concern. Some of the assumptions on which published figures are based, however, are debateable. For example, in one calculation where it is claimed that the water requirement is $15500 \mathrm{~L} / \mathrm{kg}$ beef, it is assumed that it takes three years to produce $200 \mathrm{~kg}$ of boneless beef (paper cited by Scollan et al., 2010). In the estimate, only $155 \mathrm{~L}$ of water were calculated for drinking, cleaning and post farm gate activities, the remainder being accounted for by irrigation of the crops to be used for feed of the cattle and the rain that fell on the property. The estimates of water utilized for $1 \mathrm{~kg}$ pork $(4800 \mathrm{~L}), 1 \mathrm{~kg}$ chicken $(3900 \mathrm{~L})$ and $1 \mathrm{~L}$ milk $(1000 \mathrm{~L})$ also appear extreme. These figures have been widely quoted by anti-livestock activists. In studies with more realistic and justifiable assumptions, it was calculated that the water requirement for red meat production was $18 \mathrm{~L} / \mathrm{kg}$ to $540 \mathrm{~L} / \mathrm{kg}$ (Peters et al., 2010) and $80 \mathrm{~L} / \mathrm{kg}$ to $320 \mathrm{~L} / \mathrm{kg}$ (Meissner, 2012), the large variation being due to differences in production systems and efficiency. For the production of total milk solids in whole milk and in skim milk powder the water requirement is $14.4 \mathrm{~L} / \mathrm{kg}$ and $15.8 \mathrm{~L} / \mathrm{kg}$, respectively (Ridoutti et al., 2010). The water needs of the animal itself constitute a major contributor to the total requirement, which amounts to about $4 \mathrm{~L}$ per $\mathrm{kg}$ feed dry matter intake, with a $50 \%$ increase in hot weather. Based on the direct water needs of pigs, farmers in South Africa supply $4.52 \mathrm{~m}^{3}$ /day for a 100 sow unit (Streicher, 2011).

The argument is sometimes advanced that the water used in livestock production should be channelled to crop and vegetable production, which require less water (McMichael \& Ainslie, 2010; WWF, 2010). In the paper cited by Scollan et al. (2010), it was calculated that crop species require $900 \mathrm{~L}$ to $3300 \mathrm{~L}$ of water per $\mathrm{kg}$, whereas meat production requires $3800 \mathrm{~L} / \mathrm{kg}$ to $15500 \mathrm{~L} / \mathrm{kg}$. However, this argument is futile, since it does not take into consideration water quality, economics and availability or that marginal soils are not suitable for crop production and therefore fit only for livestock production. Water used for livestock production in extensive systems originates mainly from subterranean sources and is not in competition with runoff water to streams, dams, etc., or water stored in underground aquifers that may be used for other forms of production, industries or human beings.

Chapagain \& Hoekstra (2004) calculated that agriculture accounts for $86 \%$ of global water consumption. Most of this is rainwater, which is used for the production of crops. However, it is not only about total water use per se, but about water use compared with water resources and competing demands of human being and agriculture. According to Bennie \& Hensley (2001) agriculture consumes $74.5 \%$ of the rainfall in South Africa. From this, $60 \%$ is utilized by natural vegetation, $12 \%$ by dry land crop production and $2.5 \%$ by irrigation. However, natural vegetation (rangelands) and dry land crop production use only "green" water, that is, rain water that is stored in the soil after precipitation. It is called "green" water because only green plants growing in the soil utilize this water. It cannot be used by or for anything else. In extensive grazing systems the natural vegetation that is the food source of livestock uses only green water. These extensive grazing systems are often in areas unsuitable for crop production because of inadequate rainfall and poor quality of soils. The quantity of water used for the production of livestock products (e.g. kg meat) in the extensive rangeland areas is therefore irrelevant in the calculation of water consumption for beef production. Natural rangelands that are not utilized by livestock or game would result in water being wasted.

In terms of food production, green water can only be used for the production of meat and other animal produce under extensive grazing systems on natural rangelands, as in South Africa. These systems are critical to providing food security in such areas, which dominate almost all less developed countries. Natural rangelands in these areas do not use "blue" water (runoff water to streams, dams, etc., or water stored in underground aquifers) (SIWI IFPRI IUCN IWMI, 2005; Falkenmark \& Rockström, 2006). This is completely different from intensive systems of Europe and North America. Since only the rain that infiltrated the soil is used, there is no water cost for the production of the rangeland. Nothing needs to be done to capture or extract this water other than applying good rangeland management to ensure dense basal vegetation cover to avoid excessive runoff that would lead to damaging floods, erosion, silting up of dams, etc. 
Post farm gate, there is concern about the efficiency of water usage in abattoirs and processing plants (Meissner et al., 2012) as water appears to be used inefficiently and wasted. This includes effluent from abattoirs and dairy factories.

\section{Future outlook}

The argument to replace livestock with fruits, grains and vegetables to feed people implies that all sources of food production require a similar and equal quantity and quality of resources. This is an invalid point of departure. Large regions are completely unsuitable for growing such crops and animal production is the most sustainable method of food production in these areas. Thus, a switch from livestock to fruits, grains and vegetables would have implications for food security in Africa and other developing countries. There is also uncertainty whether GHG emissions will be reduced by hungry people eating fruits, grains and vegetables directly instead of meat, since much of the energy is lost during the conversion of matter from plant origin to animal (human) matter (Garnett, 2009).

An effective way to reduce the carbon and water footprint of livestock is to reduce livestock numbers and to increase the production per animal, thereby improving their productivity. There is sufficient genetic variation in South African livestock genetic resources to facilitate breeding for improved production efficiency. One such strategy is the effective use of crossbreeding. Crossbreeding has the potential to increase weaning weight by up to $26 \%$ per cow exposed to mating, while the feed energy requirement may increase by only 1\% (MacNeil \& Newman, 1991; MacNeil, 2005).

Greenhouse gas emissions and water use per unit livestock output in South Africa can be reduced substantially by addressing the comparatively low fitness performance of animals in terms of reproductive rate and longevity. (Meissner et al., 2012). For example, the estimated calving percentages for beef cattle are $35 \%$ in the communal sector and 62\% in the commercial sector (Scholtz \& Bester, 2010), whereas a study of the erosion rate of South African Jersey cattle (Du Toit et al, 2004) indicated that their productive herd life had declined from 7.9 lactations in 1970 to 2.3 lactations in 2003.

Alternative traits to improve production through selection within breeds are residual feed intake (RFI) and residual daily gain (RDG) (Arthur et al., 1996; MacNeil et al., 2011). Residual feed intake is the difference between the actual feed intake of an animal and that expected for the observed rate of gain. Residual daily gain is the growth rate expressed as a deviation from the expected growth of an animal based on its feed intake. A low RFI value indicates a more efficient animal. Many studies have found produced heritability estimates that vary from 0.28 to 0.58 (Crews et al., 2003). In selection for low RFI animals, methane production and energy lost as methane were $28 \%$ lower in low RFI steers compared with high RFI steers (Nkrumah et al., 2006). In order to calculate RFI and RDG, it is necessary to measure individual feed intake of animals. The cost of and difficulty in measuring individual feed intake make these traits strong candidates for marker-assisted selection. Possible genetic markers for RFI have been investigated, but the success rate has been low (Moore et al., 2009).

Other strategies that should be investigated include systems and management strategies to reduce the carbon and water footprint of livestock, manipulation of nutrition to reduce methane production, and breeding of new forage and pasture cultivars with lower $\mathrm{CH}_{4}$ emissions.

Downstream aspects that need attention include techniques to accurately measure GHG, carbon sequestration and water footprint; databases of national and regional emission figures; methane capturing and energy generating units/plants; treatment of manure and waste that limits $\mathrm{CH}_{4}$ release and water use; management of agricultural wastes and effluents to limit water pollution; and application of techniques and methods to earn carbon credits from the livestock value chain.

Furthermore, it is important to promote efficient use of the green water in extensive grazing through good rangeland management systems. This will result in the production of more fodder, increasing animal product per unit of water. A dense, productive vegetative cover will promote increased $\mathrm{CO}_{2}$ sequestration while it will reduce the unproductive run-off of water, thus lessening downstream flood damage, soil erosion and silting up of dams, estuaries, etc., while giving more steady water flows over long periods.

\section{Conclusion}

Differences in production systems between countries and regions can have an effect on the carbon and water footprint of livestock products. Current methods to estimate these footprints are based largely on generic values that do not make provision for production systems. The series of articles on livestock 
greenhouse gas emission inventories for the various species in South Africa that are published in this special issue present more accurate values on the carbon footprint for the South African production systems. This paper attempts to give a balanced view on livestock production in relation to greenhouse gases and water usage to ensure that politicians, decision makers and the public are properly and correctly informed about the impact of livestock on GHG production and water usage, and it is trusted that they will note the key issues. Continued efforts are essential to convey a balanced view to the public of the contribution of livestock to global warming and its water usage, while actively countering the misleading propaganda of activist groups against animal agriculture.

Methods and innovative ways must be developed to reduce the GHG production from livestock. The livestock industries should recognize the effect of livestock on climate change and support strategies to mitigate it. No single organization or industry in South Africa can do this research and its implementation on its own. Academics, researchers and industries should combine their efforts. The establishment of a virtual centre of excellence, with the objectives of sharing research expertise and information, building capacity and conducting research and development studies should be a priority.

\section{Acknowledgement}

This work is based on research supported in part by Red Meat Research and Development South Africa and the National Research Foundation of South Africa, under grants UID 75123 and 85281.

The Grantholder acknowledges that opinions, findings and conclusions or recommendations expressed in any publication generated by the NRF supported research are that of the authors and that the NRF accepts no liability whatsoever in this regard.

\section{References}

AAFRD, 2004. Alberta Agriculture, Food and Rural Development-Manure Management and Greenhouse Gases. http://www1.agric.gov.ab.ca/\$department/deptdocs.nsf/all/cl9706/\$File /GHGBulletinNo11Manuremanagement.pdf

Arthur, P.F., Herd, R.M., Wright, J., Xu, G., Dibley, K. \& Richardson, E.C., 1996. Net feed conversion efficiency and its relationship with other traits in beef cattle. Proc. Aust. Soc. Anim. Prod. 21, 107-110.

Bennie, A.T.P. \& Hensley, M., 2001. Maximizing precipitation utilization in dryland agriculture in South Africa - a review. J. Hydrology 241, 124-139.

Biotech LTD., 2009. Agribusiness and Climate Change Seminar: Nutrition and low methane diet. Figures obtained from IPCC 1996 National Emissions. June 16th, 2009. www.neembiotech.com

Capper, J.L., 2010. The environmental impact of conventional, natural and grass-fed beef production systems. Proc. Greenhouse Gases and Anim. Agric. Conf. 2010, Banff, Canada.

Capper, J.L., 2011. Replacing rose-tinted spectacles with a high-powered microscope: The historical versus modern carbon footprint of animal agriculture. Animal Frontiers 1, 26-32.

Capper, J.L., Cady, R.A. \& Bauman, D.E., 2009. The environmental impact of dairy production: 1944 compared with 2007. J. Anim. Sci. 87, 2160-2167.

Chapagain, A.K. \& Hoekstra, A.Y., 2004. Water footprint of nations. Volume 1: Main report. Value Water Res. Ser. 16. The Netherlands, UNESCO-IHE.

Chimonyo, M., Kusina, N.T., Hamudikuwanda, H. \& Nyoni, O., 1999. A survey on land use and usage of cattle for draught in a smallholder farming area of Zimbabwe. J. Appl. Sci. Southern Afr. 5, 111-121.

Clark, H., Klein, C. \& Newton, P., 2001. Potential management practices and technologies to reduce nitrous oxide, methane and carbon dioxide emissions from New Zealand Agriculture. Ngaherehere, NZ: Ministry of Agriculture and Forestry. www.maf.govt.nz/mafnet/rural-nz/sustainable-resourceuse/climate/green-house-gas-migration/ghg-mitigation.htm.

Crews Jr., D.H., Shannon, N.H., Genswein, B.M.A., Crews, R.E., Johnson, C.M. \& Kendrick, B.A., 2003. Genetic parameters for net feed efficiency of beef cattle measured during post-weaning growing versus finishing periods. Proc. West. Sect. Am. Soc. Anim. Sci. 54, 125-128.

Dovie, D.B.K., Shackleton, C.M. \& Witkowski, E.T.F., 2006. Valuation of communal area livestock benefits, rural livelihoods and related policy issues. Land Use Policy 23, 260-271. 
Du Toit, J., Olivier, J.J. \& Van Wyk, J.B., 2004. An investigation into erosion rate of lactation records in South African Jersey cattle. Proc 2nd Joint Congr. Grassland Soc. and S. Afr. Soc. Anim. Sci., Goudini, South Africa, 118.

Falkenmark, M. \& Rockström, J., 2006. The new blue and green water paradigm: Breaking new ground for water resources planning and management. J. Water Res. Planning Manag. pp. 129-132.

Ferrell, C.L. \& Jenkins, T.G., 1982. Efficiency of cows of different size and milk production potential. RLHUSMARC. Germ Plasm Evaluation Report 10, 12.

Garnett, T., 2009. Livestock-related greenhouse gas emissions: Impacts and options for policy makers. Environ. Sci. Policy 12, 491-503.

Garnett, T., 2010. Intensive versus extensive livestock systems and greenhouse gas emissions. Food Climate Research Network briefing paper, January 2010.

Gibson, J., 2010. Open Discussion: Will genetic improvement make a significant contribution to reduction in greenhouse gas emissions in livestock? $9^{\text {th }}$ Wrld Congr. Genet. Appl. Livest. Prod. www.wcgalp2010.org.

IPCC, 2007. Climate Change 2007: The Physical Science Basis Contribution of Working Group I to the Fourth Assessment Report of the Intergovernmental Panel on Climate Change. Eds: Solomon, S., Qin, D., Manning, M., Chen, Z., Marquis, M., Averyt, K.B., Tignor, M. \& Miller, H.L., Cambridge University Press, Cambridge, United Kingdom and New York. pp. 996.

Laker, M.C., 2005. The global impact of zinc micronutrient deficiencies. Proc. Combined FSSA \& SASRI Symp. on Micronutrients in Agric.: Demands of Subtr. Crops, Mt. Edgecombe, South Africa.

MacNeil, M.D., 2005. Beef Cattle Management: Crossbreeding. In: Encyclopedia of Animal Science. Marcel Dekker, New York.

MacNeil, M.D. \& Newman, S., 1991. Using heterosis to increase profit. Proc. Int. Beef Symp. Great Falls, Montana. pp. 129-134.

MacNeil, M.D., Lopez-Villalobos, N. \& Northcutt, S.L., 2011. A prototype national cattle evaluation for feed intake and efficiency of Angus cattle. J. Anim. Sci. 89, 3917-3923.

McMichael, A.J. \& Ainslie, J.B., 2010. Environmentally sustainable and equitable meat consumption in a climate change world. In: The Meat Crisis: Developing More Sustainable Production and Consumption. Eds: D’Silva, J. \& Webster, J., Published by Earthscan LTD., London. pp. 173-189.

Meissner, H.H., 2012. Perspektief: Waterverbruik van Vee. RPO Nuusbrief, Mei 2012. www.rpo.co.za

Meissner, H.H., Scholtz, M.M. \& Schönfeldt, H.C., 2012. The status, socio-economic and environmental impact, and challenges of livestock agriculture in South Africa. www.rmrdsa.co.za

Moore, S.S., Mujibi, F.D. \& Sherman, E.L., 2009. Molecular basis for residual feed intake in beef cattle. J. Anim. Sci. 87, 41-47.

Nkrumah, J.D., Okine, E.K., Mathison, G.W., Schmid, K., Li, C., Basarab, J.A., Price, M.A., Wang, Z. \& Moore, S.S., 2006. Relationship of residual feed intake and metabolic rate, methane production and energy partitioning in beef cattle. J. Anim. Sci. 84, 145-153.

Peters, G.M., Wiedemann, S.G., Rowley, H.V. \& Tucker, R.W., 2010. Accounting for water use in Australian red meat production. Int. J. Life Cycle Assess. 15, 311-320.

Pitesky, M.E., Stackhouse, K.R. \& Mitloehner, F.M., 2009. Clearing the air: Livestock’s contribution to climate change. Adv. Agron. 103, 1-40.

Renault, D. \& Wallender, W.W., 2000. Nutritional water productivity and diets. Agric. Water Management 45, 275-296.

Ridoutti, B.G., Williams, S.R.O., Baud, S., Fraval, S. \& Marks, N., 2010. The water footprint of dairy products: Case study involving skim milk powder. J. Dairy Sci. 93, 5114-5117.

RMRD SA, 2012. Research and development plan for the large and small stock meat industries in South Africa, 2012-2013. www.rmrdsa.co.za

Scholtz, M.M. \& Bester, J., 2010. Off-take and production statistics in the different South African cattle sectors: Results of a structured survey. Appl. Anim. Husb. Rural Dev. 3, 19-22.

Scollan, N., Moran, D., Joong Kim, E. \& Thomas, C., 2010. The environmental impact of meat production systems. Report to the International Meat Secretariat, 2 July 2010.

SIWI, IFPRI, IUCN \& IWMI, 2005. 'Let it reign. The new water paradigm for global food security'. Final report to CSD-13. Stockholm International Water Institute, Stockholm. URL: www.siwi.org. 
Steinfeld, H., Gerber, P., Wassenaar, T., Castel, V., Rosales, M. \& de Haan, C., 2006. Livestock’s long shadow: Environmental issues and options. Rome, FAO, pp. 390.

Streicher, S., 2011. SAPPO guidelines to farmers. www.sapork.biz/

Thornton, P.K., 2010. Livestock production: Recent trends, future prospects. Phil. Trans. R. Soc. B 365, 2853-2867.

UNFCCC, 2007. United Nation Framework Convention on Climate Change. Available at: http://unfccc.int/kyoto_protocol/items/2830.php.

US-EPA. United States Environmental Protection Agency. 2006. International analyses. Washington: EPA. Available in: <http://www.epa.gov/methane/intlanalyses.html.

Wilkie, A.C., 2005. Anaerobic digestion of dairy manure: Design and process considerations. In: Dairy Manure Management: Treatment, Handling and Community Relations. Cornell University, Ithaca, New York.

WWF, 2010. Agriculture in South Africa: Facts and trends. World Wildlife Fund. www.wwf,org.za 